\title{
Studying polymorphic variants of the NAT2 gene (NAT2*5 and NAT2*7) in Nenets populations of Northern Siberia
}

\author{
Roza Pavlovna Tiis ${ }^{12^{*}}$ (D) Ludmila Pavlovna Osipova ${ }^{1,2}$, Daria Veniaminovna Lichman ${ }^{1,2}$, \\ Elena Nikolaevna Voronina ${ }^{2,3}$ and Maxim Leonidovich Filipenko ${ }^{2,3}$ \\ From 11th International Young Scientists School "Systems Biology and Bioinformatics" - SBB-2019 \\ Novosibirsk, Russia. 24-28 June 2019
}

\begin{abstract}
Background: $\mathrm{N}$-acetyltransferase 2 plays a crucial role in the metabolism of a wide range of xenobiotics, including many drugs, carcinogens, and other chemicals in the human environment. The article presents for the first time data on the frequency of two important "slow" variants of NAT2 gene (NAT2*5, rs1801280 and NAT2*7, rs1799931), which significantly affect the rate of xenobiotics acetylation, among representatives of indigenous populations of Forest and Tundra Nenets in Northern Siberia. The aim of this study was to identify the frequencies of these variants and compare them with frequencies in other ethnic populations.

Results: NAT2*5 (T341C) genotyping revealed frequencies of $28,0 \%$ and $38,6 \%$ for Tundra and Forest Nenets, respectively. The frequencies of NAT2*7 (G857A) variant were 9,8\% and 8,2\% for Tundra and Forest Nenets, respectively. Polymorphic variants frequencies for Nenets are intermediate between those in populations of Europeans and Asians. These results can probably be explained by the presence of both European and Asian components in Nenets gene pools.

Conclusions: The results of this study expand the knowledge of NAT2 polymorphism in world populations. These data may also help assess the genetic predisposition of Nenets to multifactorial diseases associated with polymorphism in the NAT2 gene and, in general, contribute to the development of personalized medicine in reference to native people of Siberia.
\end{abstract}

Keywords: Xenobiotics, NAT2 gene, NAT2*5, rs1801280, NAT2*7, rs 1799931, Forest and Tundra Nenets, Northern Siberia

\section{Background}

A person's life expectancy and quality of life are determined by many factors, including heredity, lifestyle, physical activity, nutrition, stress, and the exposure to foreign substances (xenobiotics). These include exotoxins, mutagens and carcinogens in tobacco smoke, food, air, medicines, industrial and agricultural products [1-3].

\footnotetext{
* Correspondence: kruosana@mail.ru

${ }^{1}$ Institute of Cytology and Genetics SB RAS, 630090 Novosibirsk, Russia

${ }^{2}$ Novosibirsk State University, Russian Federation, 630090 Novosibirsk, Russia

Full list of author information is available at the end of the article
}

Foreign substances entering the body are metabolized by the enzymes of the xenobiotic biotransformation system (XBS). XBS genes are highly polymorphic. Numerous studies have shown that the combination of adverse environmental factors with the inheritance of unfavorable polymorphic variants of genes, which include XBS genes, determines individual sensitivity to various toxins. Such sensitivity may contribute to the development of socially significant diseases in both adults and children. Similarly, resistance or hypersensitivity of an individual to a particular drug may lead to lack of therapeutic effect

(c) The Author(s). 2020 Open Access This article is licensed under a Creative Commons Attribution 4.0 International License, which permits use, sharing, adaptation, distribution and reproduction in any medium or format, as long as you give appropriate credit to the original author(s) and the source, provide a link to the Creative Commons licence, and indicate if changes were made. The images or other third party material in this article are included in the article's Creative Commons licence, unless indicated otherwise in a credit line to the material. If material is not included in the article's Creative Commons licence and your intended use is not permitted by statutory regulation or exceeds the permitted use, you will need to obtain permission directly from the copyright holder. To view a copy of this licence, visit http://creativecommons.org/licenses/by/4.0/ The Creative Commons Public Domain Dedication waiver (http://creativecommons.org/publicdomain/zero/1.0/) applies to the data made available in this article, unless otherwise stated in a credit line to the data. 
or development of adverse reactions in response to treatment [4-14].

The process of xenobiotic metabolism in the body occurs in three stages or phases. The first phase, the activation phase, is carried out by a large family of cytochrome P450 enzymes (CYPs). The second phase involves various transferases and hydrolases that neutralize hydrophilic and often toxic phase I products. During the third phase, the xenobiotic compounds may are removed from cells by energy-dependent transporters to the extracellular medium, where they may be further metabolized or excreted $[15,16]$.

For the most effective neutralization of many foreign substances, it is necessary to have the combined action of enzymes from phases I and II. It has been revealed that the desynchronization of the biotransformation phases leads to the accumulation of peroxidation products, carcinogens and mutagens in the organism, leading to its rapid poisoning. Especially unfavorable is the combination of high activity of phase I enzymes and low activity of phase II enzymes [17-19]. Among the phase II enzymes, the families of glutathione-S-transferases (GSTs) and N-acetyltransferases (NATs) display the widest and most diverse activity [20].

There are two functional isoenzymes in NAT family, which metabolize a wide range of xenobiotics. These include carcinogens such as aromatic amines (4-aminobiphenyl), heterocyclic amines (2-amino-1-methyl-6-phenylimidazo [4, 5-b]pyridines) contained in cigarette smoke and food [21]. The enzyme NAT1 is involved in the metabolism of folate, para-aminosalicylic and para-aminobenzoic acids. NAT2 is considered the main enzyme of xenobiotic acetylation. It is responsible for the biotransformation of a wide range of clinically important drugs (antihypertensive, hydrazine, hydralazine, phenelzine; arylamine drugs, including antiarrhythmic procainamide and sulfametazine of the antibacterial spectrum, anti-tuberculosis isoniazid, etc.) [22].

The NAT1 and NAT2 genes are located on the same chromosome, in the $8 \mathrm{p} 21.3-23.1$ region. These genes do not contain introns in their structure, have an open reading frame with a length of 870 nucleotide pairs, and have $87 \%$ of the nucleotide sequence homology of the coding region, but are regulated independently of each other [21, 23, 24]. NAT1 is expressed in most body tissues, while NAT2 is active in the liver, intestine, and breast tissue [21-23, 25, 26].

The NAT1 and NAT2 genes are highly polymorphic [21]. Our study is focused on the NAT2 gene since it is considered the main enzyme of xenobiotic acetylation [22]. There are 16 polymorphic sites in this gene, including 15 SNPs and one deletion resulting in a frame shift [27]. Different combinations of these polymorphisms produce 36 variants of the NAT2 gene; each of these combinations encodes an enzyme with different acetylation rate. In the NAT2 gene, the "wild" type variant that is responsible for "fast" acetylation is referred to as NAT2*4. Three main "slow" variants have also been identified. The NAT2*5 variant (rs1801280, T341C) leads to the replacement of isoleucine with threonine at the position 114 of the protein molecule and causes a decrease in the maximum acetylation rate of $\mathrm{N}$-acetyltransferase 2. Variant $N A T 2 * 6$ (rs1799930, G590A) results in the replacement of arginine with glutamine at the position 197 of the protein molecule. And the third variant is the NAT2*7 (rs 799931, G857A) leading to the replacement of glycine with glutamine in the 286th position of the protein chain. The latter two variants cause the formation of a less stable enzyme molecule. Heterozygotes for the "fast" and "slow" variants display intermediate rate of acetylation [21, 28-30].

The frequencies of "slow" variants of the NAT2 gene vary in human populations. It is well known that the average frequency of $N A T 2 * 5$ is $50 \%$ among Europeans, $33-42 \%$ among Africans, and it is quite low (about 5\%) among Asians. The NAT2*6 is common in all of these populations with a frequency of about $30 \%$. As for the $N A T 2 * 7$, its frequency is low enough for Europeans (less than 2\%) and Africans (3-6\%), and it reaches 10-12\% among Asians [31-34]. It has been shown that NAT2*6 and $N A T 2 * 7$ frequencies are 32.9 and $2.7 \%$, respectively, in Europeans from Novosibirsk, Russia [35]. Among the Europeans of the Moscow region, the frequencies of $N A T 2 * 5, N A T 2 * 6$ and NAT2 $* 7$ variants were found to be $46.8,19.3$ and $2.9 \%$, respectively [36].

Studying polymorphisms in the NAT2 gene is clinically important due to the association identified between polymorphisms in this gene and the development of various socially significant diseases, as well as the sensitivity of individuals to drugs, such as isoniazid, that are used to treat tuberculosis [1, 37]. Numerous studies have shown a reliable link between polymorphic variants of NAT genes and the risk of cancer, including cancer of the head and neck, lungs, mammary glands, larynx, bladder, digestive tract [3845]. The presence of a "slow" NAT2 genotype in combination with a "zero" GSTM1 (0/0) genotype is a risk factor for the development of lymphatic leukemia in children [46]. CYP1A1 Val, NAT2*6 (G590A) variants and GSTM1 (0/0) genotype are associated with a predisposition to bronchial asthma development in children [47]. A study conducted in the Krasnodar Region of Russia showed that the presence of the NAT2 6 (590A/A) genotype increases by a factor of 3.5 the risk of developing congenital malformations such as cleft lip and/or palate in females compared to males [48].

Certain NAT2 genotypes and some lifestyle features can be considered as combined risk factors for the development of psoriasis in a sample of Muscovites [49]. It has been shown that polymorphic variants of the GSTT1, 
GSTM1, and NAT2 genes can potentially modulate the risk of tuberculosis development in ethnic Russians [50]. Certain polymorphic variants of GSTT1, GSTM1, NAT2, and MTRR genes can modulate the risk of acute leukemia in children living in the European part of Russia [51]. In Yakuts, the allele $N A T 2 * 7$ (857A) and the genotype NAT2 $\%(857 \mathrm{G} / \mathrm{A})$ are markers of increased risk of lung cancer [52].

Since the 1960s, in the northern areas of Western Siberia, the development of industry has been growing. This had led to changes in the traditional way of life for indigenous ethnic groups and the introduction of new chemicals, drugs and toxic pollutants into their habitats. Therefore, it is necessary to determine whether these indigenous ethnic groups are resistant to these xenobiotics and whether there is a high risk of exposure of the population that leads to serious health issues, such as respiratory diseases, cancer and allergies. For this purpose, it is necessary to study the genetic profile of indigenous populations and their ability to metabolize xenobiotics.

Ethnography, anthropology, demographic history of indigenous Nenets populations and genetic markers such as polymorphism in genes GSTM1, GSTT1, CYP2C9, and CYP2D6 associated with xenobiotics metabolism have been studied previously [53-61].

In this study, we analyzed the occurrence of $N A T 2 * 5$ (rs1801280, T341C) and NAT2*7 (rs1799931, G857A) variants of the NAT2 gene in the populations of Tundra and Forest Nenets of the Yamalo-Nenets Autonomous Okrug (YaNAO).

\section{Results}

The frequencies of the studied polymorphic variants of the NAT2 gene in Nenets and other world populations are shown in Table 1. The data were collected according

Table 1 NAT2*5 and NAT2*7 variant frequencies of the NAT2 gene in some human populations, $\%$

\begin{tabular}{lll}
\hline Population & NAT2*5 (341C) & NAT2*7 (857A) \\
\hline Tundra Nenets ${ }^{\mathrm{a}}$, YaNAO, Russia & $28.0(n=182)$ & $9.8(n=194)$ \\
Forest Nenets ${ }^{\mathrm{a}}$, YaNAO, Russia & $38.6(n=290)$ & $8.2(n=330)$ \\
Tatars, Bashkiria region, Russia [62] & No data & $9.5(n=136)$ \\
Europeans, Moscow, Russia [49] & $42.0(n=198)$ & $3.0(n=198)$ \\
Russians, Voronezh region, Russia [63] & $42.0(n=580)$ & $3.0(n=580)$ \\
Germans, Germany [31] & $46.5(n=1688)$ & $1.3(n=1688)$ \\
Romanians, Central Europe [64] & $43.5(n=280)$ & $3.2(n=280)$ \\
Egyptians [65] & $49.7(n=400)$ & $2.8(n=400)$ \\
Kyrgyz, Central Asia [64] & $19.3(n=580)$ & $12.1(n=580)$ \\
Han Chinese, China [66] & $1.8(n=224)$ & $17.0(n=224)$ \\
Bantu, Africa [34] & $38.3(n=204)$ & $6.1(n=204)$ \\
\hline
\end{tabular}

$n$ number of alleles examined; a own study the established protocols [67] and the results were confirmed by the statistical estimates $[68,69]$.

\section{NAT2*5 T341C (Ile114Thr)}

Genotype counts in Forest and Tundra Nenets were as follows: $T T-55$ and 45; $T C-68$ and $41 ; C C-22$ and 5 respectively. In each sample, the distribution of NAT2*5 (T341C) frequencies reflected Hardy-Weinberg equilibrium $\left(x^{2}=0.017, p=0.896\right.$ and $\chi^{2}=1.244, p=$ 0.265 for Forest and Tundra Nenets).

The frequency of the "slow" NAT2*5 (T341C) variant in the Tundra Nenets was statistically significantly lower $(28.0 \%)$ than in the Forest Nenets (38.6\%), $p=0.024$.

\section{NAT2*7 G857A (Gly286GIn)}

Genotype counts in samples of Forest and Tundra Nenets were as follows: $G G-139$ and 78; $G A-25$ and 19; $A A-$ 1 and 0 , respectively. An additional file contains more detailed information on individual genotyping results (See Additional File 1). In both samples, the distribution of frequencies NAT2*7 (G857A) reflected Hardy-Weinberg equilibrium $\left(x^{2}=0.012, p=0.914\right.$ and $x^{2}=1.143, p=$ 0.285 for Forest and Tundra Nenets, respectively).

The frequencies of the "slow" NAT2*7 (857A) variant in the study populations did not statistically differ from each other, with Forest and Tundra Nenets having essentially the same values (8.2 and 9.8\%, $\chi^{2}=0.22 ; p=0.64$ ).

\section{Discussion}

As described above, the polymorphic variant NAT2*5 $(341 C)$ is found in the world populations with an average frequency of $30-50 \%$ among Europeans, 33-42\% among Africans, and quite rarely among Asians (up to 5\%). The results of our study showed that the frequencies of the NAT2*5 (341C) variant in Forest Nenets and Europeans did not statistically significantly differ. Tundra Nenets, by contrast, have a statistically significantly lower frequency of NAT2*5 compared to the comparative populations (Russians, Romanians, Germans, Egyptians, Bantu Africans), as well as Forest Nenets (in all cases of pairwise comparison $p<0.05)$. In addition, there are statistically significant differences between the Nenets and Kyrgyz, as well as with Han Chinese, for whom the frequency of $N A T 2 * 5(341 C)$ is low enough, as in other Asian populations $(p<0.05)$.

We have mentioned above that the frequency of $N A T 2 * 7$ (857A) is low for Europeans (less than 2\%) and Africans (3-6\%), and among Asians it reaches $10-12 \%$. Our study showed that with respect to the frequency of the NAT2*7 (857A) variant, both Forest and Tundra Nenets are statistically significantly different from Russians, Romanians, Germans, and Egyptians $(p<0.05)$, although there are no statistically significant differences with Africans, Kyrgyz, and Tatars. 
In Forest and Tundra Nenets, the frequencies of "slow" polymorphic variants NAT2*5 and NAT2*7 of one of the key genes of the xenobiotics biotransformation system, including carcinogens and the main clinically important drugs, occupy an intermediate value between the frequencies among the considered populations of Europeans and Asians. Such results can probably be explained by the presence in the gene pools of the Nenets, both European and Asian components, which were determined according to anthropological and genetic data [53-60].

Based on our data on lower frequencies of the "slow" NAT2*5 variant in Nenets, compared with Europeans, we can assume that at the population level these northern peoples, unlike the studied European populations, are at a lower risk of developing cancer and other multifactorial diseases with which a polymorphic variant of NAT2*5 is associated. Especially since the standardized mortality rate from cancer in the Yamalo-Nenets okrug in 2017 fell below the level in the Russian Federation [61]. However, to confirm our assumption, it is necessary in the future to use additional population genetic parameters and the necessary statistical methods of data processing.

\section{Conclusion}

Currently, changes in the habitual way of life of indigenous ethnic groups are taking place due to the crossbreeding of the population and the rapid development of industry in the Yamalo-Nenets Autonomous Okrug. New chemical substances and carcinogens penetrate into the Nenets' habitat. The development of medicine, in turn, contributes to the active penetration of drugs. Changing standards of treatment require the use of more and more new medicines, which indigenous peoples have never encountered before.

Therefore, having an idea about polymorphic variants frequencies of the genes of the xenobiotic biotransformation system, which include medicinal products, and hence the peculiarity of their metabolism in indigenous Samoyedic ethnic groups, it is possible to plan the safest and most effective therapy with medicines. Knowledge about the distribution of polymorphic variants of genes in the xenobiotic biotransformation system allows us to identify genotypes associated with socially significant, multifactorial diseases, which makes it possible to identify predisposition to them and to take preventive measures to avoid the development of pathological conditions.

\section{Methods}

\section{Study populations}

To conduct the study, samples of representatives of Tundra and Forest Nenets living in the Purovsky region of the YaNAO were obtained. These samples did not include descendants of intermarriages with Russians and other ethnic groups. The material for the study was collected during the 1988-2009 expeditions to the YaNAO under the guidance of L. P. Osipova. Peripheral blood collection was carried out according to international rules [67] with the use of genealogical information and "Informed consent" from volunteers who were healthy at the time of the study.

\section{DNA isolation and SNP genotyping}

DNA samples were isolated from the leukocyte fractions of venous blood by the standard method of phenol-chloroform extraction using proteinase K. Genotyping of NAT2:5 (T341C) and NAT2*7 (G857A) SNPs of NAT2 gene was performed using real-time PCR with competing TaqManprobes carrying a quencher at the 3 '-end and different fluorescent dyes (FAM or R6G) at the $5^{\prime}$-end. Probe sequences for NAT2*5 (T341C) were as follows: 5'-FAM-CAGGTG ACCATTGACGGCAG-BHQ-3' и 5'-R6G-CAGGTGAC CACTGACGGCAG -BHQ-3'.

Probe structures for NAT2*7 (G857A): 5'-FAM-CCAA ACCTGGTGATGAATC-BHQ-3' and 5'-R6G-CCAA ACCTGGTGATGGAT-BHQ-3'. The primer sequences for NAT2*5 (T341C) were as follows:

\section{NAT2-RT-U1 agcactggcatggttcac}

\section{NAT2-RT-R3 GTTTCTTCTTTGGCAGGAGATGAG}

In the case of $N A T 2 * 7$ (G857A) primers had such structures:

\section{NAT2-RT-U3 ctgaggaagaggttgaagaagtg}

\section{NAT2-803R GTTGGGTGATACATACAGAAGGG}

The total volume of the reaction mixture was $8 \mu$, the mixture contained DNA with a concentration of $15 \mathrm{ng} / \mu \mathrm{l}$, $300 \mathrm{nM}$ of each primer; $100-200 \mathrm{nM}$ each of Taqman probes conjugated with FAM or R6G; $200 \mu \mathrm{M}$ dNTPs, amplification buffer $(650 \mathrm{mM}$ Tris- $\mathrm{HCl}, 240 \mathrm{mM}$ $\left(\mathrm{NH}_{4}\right)_{2} \mathrm{SO}_{4}, 0.5 \%$ Tween $20,35 \mathrm{mM} \mathrm{MgCl}$ ), thermostable Taq polymerase - 0.5 units.act./react. PCR was performed under the following conditions: initial denaturation $5 \mathrm{~min}$ at $95^{\circ} \mathrm{C}$; then 48 cycles including denaturation at $95^{\circ} \mathrm{C}$ for $10 \mathrm{~s}$, annealing of primers and subsequent elongation at $60^{\circ} \mathrm{C}$ for $40 \mathrm{~s}$ (each step was accompanied by registration of the fluorescence signal in the ranges corresponding to the fluorescence intervals of FAM and R6G fluorophores). The work was carried out using the amplifier Bio-Rad CFX manager (USA). The obtained data were processed with the help of "CFX manager" software.

\section{Statistical analysis}

The population frequencies of polymorphic variants were calculated on the basis of the observed genotype 
frequencies. The conformity of genotype frequencies to the Hardy-Weinberg equilibrium was assessed using the $X^{2}$ (Pearson) criterion, using the on-line test program (at $p>0.05$ the equilibrium is performed) [68]. In order to assess the reliability of the differences in the frequencies of polymorphic variants between population samples, the $X^{2}$ criterion with Yates correction was applied (at $p<0.05$, the results were considered to be reliably significant) [69].

\section{Supplementary information}

Supplementary information accompanies this paper at https://doi.org/10. 1186/s12863-020-00909-4.

Additional file 1. Results of genotyping of point substitutions in NAT2 gene. File containing the results of genotyping (individuals genotypes) of point substitutions NAT2 * 5 T341C (rs 1801280) and NAT2* 7 G857A (rs 1799931) by Real-time PCR. The study involved healthy volunteers, representatives of indigenous peoples, Forest Nenets and Tundra Nenets living in Purovsky district of Yamalo-Nenets Autonomous Okrug, Russian Federation, settlement Samburg for the Tundra Nenets and settlements Kharampur, Khalyasavey, Tarko-Sale for the Forest Nenets. All research participants gave a written informed consent to the clinical examination and the publication of their anonymous data.

\section{Abbreviations}

DNA: Deoxyribonucleic acid; dNTPs: deoxynucleotide triphosphates; NAT: Nacetyltransferase; PCR: Polymerase chain reaction; YaNAO: Yamalo-Nenets Autonomous Okrug; XBS: Xenobiotic biotransformation system

\section{Acknowledgments}

The authors are grateful to the Nenets people who agreed to participate in this study. We thank Moletotova N., Burlakova N., Churkina T., Vavilova N., Petrov S., Babenko V. for the technical assistance.

\section{About this supplement}

This article has been published as part of BMC Genetics Volume 21 Supplement 1, 2020: Selected Topics in "Systems Biology and Bioinformatics" - 2019: genetics. The full contents of the supplement are available online at https://bmcgenet.biomedcentral.com/articles/supplements/volume-21supplement-1.

\section{Authors' contributions}

LO managed and collected the genetics material for the study during the expeditions to the Yamalo-Nenets Autonomous Okrug, interpreted the results and corrected the manuscript. EV and MF developed a method of genotyping NAT2*5 (T341C) and NAT2*7 (G857A) single nucleotide replacements of NAT2 gene. DL interpreted the results and corrected the manuscript. RT worked out literary data, conducted genetic analysis of samples, statistical analysis of data, interpreted the results and wrote the first draft of the manuscript. All authors read and approved the final manuscript.

\section{Funding}

This work is supported by the Russian Science Foundation grant No. 19-1500219 .

The funding bodies played no role in the design of the study, research, writing and publication of the paper.

Publication costs for this article are covered by the Russian Science

Foundation (grant No. 19-15-00219).

\section{Availability of data and materials}

All data obtained and analyzed during this study is included in this published article. Individual genotyping data are available at the Novosibirsk State University site (http://lcg.nsu.ru/en/links/). The data obtained for each of the studied genetic samples are also provided in an Additional file 1.

\section{Ethics approval and consent to participate}

The study was conducted using the genetic material of healthy volunteers. Blood sampling of these individuals was carried out according to international WHO rules, using the "Informed consent" and with the approval of Ethics Committee of the Research Institute of Internal and Preventive Medicine - Branch of the Federal State Budget Scientific Institution "The Federal Research Center Institute of Cytology and Genetics" of Siberian Branch of the Russian Academy of Sciences, 17511 Borisa Bogatkova Street, Novosibirsk 630089, Russia (Protocol No 37-2001).

All research participants gave a written informed consent to the clinical examination and the publication of their anonymous data.

\section{Consent for publication}

Not applicable.

\section{Competing interests}

The authors declare that they have no competing interests.

\section{Author details}

'Institute of Cytology and Genetics SB RAS, 630090 Novosibirsk, Russia. ${ }^{2}$ Novosibirsk State University, Russian Federation, 630090 Novosibirsk, Russia. ${ }^{3}$ Institute of Chemical Biology and Fundamental Medicine SB RAS, Novosibirsk, Russia.

Published: 22 October 2020

\section{References}

1. Baranov VS, Baranova EV, Ivashchenko TE, Aseev MV. Human genome and predisposition genes. Introduction into predictive medicine: SPb: Intermedica; 2000. (in Russian). https://www.livelib.ru/publisher/44908/ books-intermedika.

2. Gichev YP. Environmental pollution and human health (the sad experience of Russia). Novosibirsk: SB RAMS; 2002. (in Russian).

3. Beresina TN. Health as a factor in the individual life expectancy of Russians in the twentieth century. Psychologist. 2017;3:72-87. ISSN: 2409-8701. https://doi.org/10.25136/2409-8701.2017.3.22781.

4. Meisel P. Arylamine $\mathrm{N}$-acetyltransferases and drug response. Pharmacogenomics. 2002;3(3):349-66.

5. Ivaschenko TE, Shvets NY, Kramareva NL, et al. Analysis of polymorphic alleles of genes encoding enzymes of the 1st and 2 nd phases of detoxification in patients with endometriosis. Genetika. 2003;39(4):525-9 (in Russian). https://www.ncbi.nlm.nih.gov/pubmed/12760253.

6. Baranov VS, Ivashchenko TE, Baranova EV. Genomics and pharmacogenetics in prevention and treatment of some common diseases in children. Curr Pediatrics. 2004;3(6):57-61 (in Russian). ISSN 1682-5535 (online).

7. Tamer L, Calikoglu M, Ates NA, et al. Glutathione-S-transferase gene polymorphisms (GSTT1, GSTM1, GSTP1) as increased risk factors for asthma. Respirology. 2004;9:493-8.

8. Lyakhovich W, Vavilin VA, Makarova SI, Grishanova AY. Ecogenetic aspect of multifactorial diseases. Vestnik VOGiS. 2006;10(3):514-9 (in Russian). ISSN 2500-3259 (online).

9. Zhuchenko NA, Umnova NV, Rumak VS, et al. Congenital morphogenetic variants and genetic polymorphism of the xenobiotic detoxification system in children from dioxin-contaminated areas of South Vietnam. Ann Russ Acad Med Sci. 2006;7:3-10 (in Russian). https://www.ncbi.nlm.nih.gov/ pubmed/16924871.

10. Shi X, Zhou S, Wang Z, Zhou I. CYPIA1 and GSTM1 polymorphisms and lung cancer risk in Chinese populations: a meta-analysis. Lung Cancer. 2008;59(2):155-63.

11. Economopoulos KP, Sergentanis TN. GSTM1, GSTT1, GSTP1, GSTA1 and colorectal cancer risk: a comprehensive meta-analysis. Eur J Cancer. 2010; 46(9):1617-31.

12. Izmerov NF, Kuzmina LP, Kolyaskina MM, et al. Polymorphism of genes of the system of biotransformation of xenobiotics in patients with occupational allergic dermatoses. Ann Russ Acad Med Sci. 2012;67(7):39-43 (in Russian).

13. Zemlyanova MA, Koldibekova YV. Modern approaches to assessment of metabolism disorders of xenobiotics during their administration into body from external environment. Hum Ecol. 2012;8:8-14 (in Russian). ISSN: 1728-0869. 
14. Zaridze DG, Mukeria AF, Shangina OV. Interaction of environmental factors and genetic polymorphism in the etiology of cancer. Adv Mol Oncol. 2016; 3(2):8-17 (in Russian).

15. Saprin AN. Enzymes of the metabolism and detoxification of xenobiotics. Success Biol Chem. 1991;32:146-72 (in Russian). ISSN: 0006-2979.

16. Kulinsky VI. Neutralization of xenobiotics. Soros Educ J. 1999;1:8-12 (in Russian). http://www.pereplet.ru/nauka/Soros/pdf/9901_008.pdf.

17. Nebert DW. Drug - metabolizing enzymes, polymorphisms and interindividual response to environmental toxicants. Clin Chem Lab Med. 2000;38:857-61.

18. Rice RK, Gulyaeva LF. Biological effects of toxic compounds. Novosibirsk: NSU; 2003. (in Russian).

19. Glotov OS, Baranov VS. Genetic polymorphism and aging. Success Gerontol. 2007;20(2):35-55 (in Russian). ISSN: 1561-9125.

20. Severin ES. Biochemistry: Textbook for high schools. M: GEOTAR_MED; 2003. (in Russian).

21. Hein DW, Doll MA, Fretland AJ, et al. Molecular genetics and epidemiology of the NAT1 and NAT2 acetylation polymorphisms. Cancer Epidemiol Biomark Prev. 2000;9:29-42.

22. Sim E, Walters K, Boukouvala S. Arylamine N-acetyltransferases: from structure to function. Drug Metab Rev. 2008;40(3):479-510.

23. Nickman D, Risch A, Buckle V, et al. Chromosomal localization of human genes for arylamine N-acetyltransferase. Biochem J. 1994;297:441-5.

24. Blum M, Grant DM, McBride W, et al. Human arylamine N-acetyltransferase genes: isolation, chromosomal localization, and functional expression. DNA Cell Biol. 1990;9:193-203.

25. Sadrieh N, Davis CD, Snyderwine EG. N-Acetyltransferase expression and metabolic activation of the food-derived heterocyclic amines in the mammary gland. Cancer Res. 1996;56:2683-7.

26. Smelt VA, Upton A, Adjaye J, et al. Expression of arylamine Nacetyltransferases in pre-term placentas and in human pre-implantation embryos. Hum Mol Genet. 2000;9(7):1101-7.

27. Human arylamine $\mathrm{N}$-acetyltransferase gene nomenclature. http://louisville. edu/medicine/departments/pharmacology/news-information/nat Accessed 26 Aug 2019.

28. N-acetyltransferase 2; NAT2. https://www.omim.org/entry/612182 Accessed 26 Aug 2019.

29. Lin HJ, Han C-Y, Lin BK, Hardy S. Slow acetylator mutations in the human polymorphic N-acetyltransferase gene in 786 Asians, blacks, Hispanics, and whites: application to metabolic epidemiology. Am J Hum Genet. 1993;52: 827-34

30. Magalon $\mathrm{H}$, Patin $\mathrm{E}$, Austerlitz $\mathrm{F}$, et al. Population genetic diversity of the NAT2 gene supports a role of acetylation in human adaptation to farming in Central Asia. Eur J Hum Genet. 2008;16:243-51.

31. Cascorbi I, Drakoulis N, Brockmoller J, et al. Arylamine N-acetyltransferase (NAT2) mutations and their allelic linkage in unrelated Caucasian individuals: correlation with phenotypic activity. Am J Hum Genet. 1995;57:581-92.

32. Sekine A, Saito $S$, lida A, et al. Identification of single-nucleotide polymorphisms (SNPS) of human N-acetyltransferase genes NAT1, NAT2, AANAT, ARD1 and LICAM in the Japanese population. J Hum Genet. 2001;46: 314-9.

33. Borlak J, Reamon-Buettner SM. N-acetyltransferase 2 (NAT2) gene polymorphisms in colon and lung cancer patients. BMC Med Genet. 2006; 7(58):1-9.

34. Oluka MN, Matimba A, Okalebo FA, et al. Characterization of inter-ethnic genetic variability of CYP2D6, CYP2C19, CYP2B6, NAT2 and GSTs in the bantu and Nilotic populations of Kenya and implications for the chemotherapy of infectious diseases. Afr J Pharmacol Ther. 2014;3(2):38-46 ISSN: 1996-0816.

35. Nikishina MV, Vavilin VA, Makarova SI, Lyakhovich W. Analysis of associations of NAT2 gene polymorphisms with a risk of lung cancer. Bull Exp Biol Med. 2007:1:89-92 (in Russian).

36. Goldenkova-Pavlova IV, Bruskin SA, Avdeev RM, et al. Comparative analysis of the results of phenotyping and genotyping of human $\mathrm{N}$-acetylation polymorphism. Genetika. 2006;42(8):1143-50 (in Russian).

37. Cetintas VB, Erer OF, Kosova B, et al. Determining the relation between Nacetyltransferase-2 acetylator phenotype and antituberculosis drug induced hepatitis by molecular biologic tests. Tuberk Toraks. 2008;56(1):81-6 ISSN: 0494-1373.

38. Drozdz M, Gierek T, Jesdryczko A, et al. N-acetyltransferase phenotype of patients with cancer of the larynx. Neoplasma (Bratisl). 1987;34:481-4.
39. Ambrosone CB, Freudenheim JL, Graham S, et al. Cigarette smoking, Nacetyltransferase 2 genetic polymorphisms, and breast cancer risk. JAMA. 1996;276:1494-501.

40. Cascorbi I, Brockmoller J, Mrozikiewicz PM, et al. Homozygous rapid arylamine $\mathrm{N}$-acetyltransferase (NAT2) genotype as a susceptibility factor for lung cancer. Cancer Res. 1996;56:3961-6.

41. Gonzales MV, Alvarez V, Pello MF, et al. Genetic polymorphism of Nacetyltransferase-2, glutathione S-transferase-M1, and cytochromes P450IIE1 and P450IID6 in the susceptibility to head and neck cancer. J Clin Pathol. 1998;51(4):294-8.

42. Wikman $\mathrm{H}$, Thiel $\mathrm{S}$, Jager $\mathrm{B}$, et al. Relevance of $\mathrm{N}$-acetyltransferase 1 and 2 (NAT1, NAT2) genetic polymorphisms in non-small cell lung cancer susceptibility. Pharmacogenetics. 2001;11(2):157-68.

43. Garcia-Closas M, Malats N, Silverman D, et al. NAT2 slow acetylation, GSTM1 null genotype, and risk of bladder cancer: results from the Spanish bladder cancer study and meta-analyses. Lancet. 2005;366(9486):649-59.

44. McKay JD, Hung RJ, Hashibe M, Wakefield J. Sequence variants of NAT1 and NAT2 and other xenometabolic genes and risk of lung and aerodigestive tract cancers in Central Europe. Cancer Epidemiol Biomark Prev. 2008;17(1):141-7.

45. Nesa A, Rahman M, Kabir Y, Rupam F. Genetic polymorphism of NAT2 gene and its association with prostate cancer. Anwer Khan Mod Med Coll J. 2014; 5(2):39-42.

46. Krajinovich M, Richer C, Sinnett $H$, et al. Genetic polymorphisms of NAcetyltransferases 1 and 2 and gene-gene interaction in the susceptibility to childhood acute lymphoblastic leukemia. Cancer Epidemiol Biomark Prev. 2000;9:557-62 https://cebp.aacrjournals.org/content/9/6/557.full.

47. Vavilin VA, Makarova SI, Lyakhovich W, et al. Association of polymorphic genes of xenobiotic biotransformation enzymes with predisposition bronchial asthma in children with hereditary burden and without it. Genetika. 2002;38(4):539-45 (in Russian)

48. Nekhoroshkina MO, Bushueva OY, Polonikov AV, et al. Association of G590A polymorphism of the NAT2 gene with congenital cleft lip and palate in Krasnodar region. Kursk Sci Pract Bull Man His Health. 2013;4:33-7 (in Russian). ISSN 1998-5754 (onlain).

49. Kozhekbaeva ZM, Gra OA, Fadeev VS, et al. Association of NAT2 polymorphism with risks to develop psoriasis and various dermatological diseases in Moscow population. Mol Biol. 2009;43(1):62-76 (in Russian).

50. Gra OA, Kozhekbaeva JM, Skotnikova Ol, et al. Analysis of the genetic predisposition to pulmonary tuberculosis in the Russian population. Genetika. 2010;46(2):262-71 (in Russian).

51. Gra OA, Glotov AS, Kozhekbaeva JM, et al. Genetic polymorphism GST, NAT2 and MTRR and predisposition to the development of acute leukemia in children. Mol Biol. 2008;42(2):214-25 (in Russian).

52. Nikolaev VM, Zasimova EZ, Alexandrova EN, et al. Analysis of associations of genetic polymorphisms 481C>T,590G $>A$ and $857 G>A$ of the enzyme $\mathrm{N}$ acetyltransferase 2 (NAT2) gene with the risk of lung cancer in Yakuts. Yakutsk Med J. 2017;3(59):34-7 (in Russian). ISSN: 2312-1017 (online).

53. Karafet TM, Osipova LP, Savina OV, et al. Siberian genetic diversity reveals complex origins of the Samoyedic-speaking populations. Am J Hum Biol. 2018:30(6):e23194.

54. Sukernik RI, Osipova LP, Karaphet TM, Abanina TA. Studies on blood groups and other genetic markers in Forest Nentzi: variation among the subpopulations. Hum Genet. 1980;55:397-404.

55. Osipova LP. Genetic markers of immunoglobulins (Gm system) for assessing migration and cross-breeding processes in human populations in northern Siberia. Contemp Probl Ecol. 1994;1(2):129-40 (in Russian). ISSN: 0869-8619.

56. Karafet TM, Osipova LP, Gubina MA, et al. High levels of $Y$ chromosome differentiation among native Siberian populations and the genetic signature of a boreal hunter-gatherer way of life. Hum Biol. 2002;16:702-22.

57. Aksyanova GA, Bogashev AN, Bogordaeva AA, et al. Ethnography and anthropology of Yamal. Novosibirsk: Science; 2003. (in Russian).

58. Tambets K, Yunusbayev B, Hudjashov G, et al. Genes reveal traces of common recent demographic history for most of the Uralic-speaking populations. Genome Biol. 2018;19(1):139.

59. Korchagina RP, Osipova LP, Vavilova NA, et al. Genetic polymorphism of cytochrome P450 2C9, involved in drug metabolism, in the populations of the indigenous inhabitants of northern Siberia. Bull SB RAMS. 2011;6:39-46 (in Russian). ISSN: 2410-2512.

60. Korchagina RP, Osipova LP, Vavilova NA, et al. Polymorphisms of the GSTM1, GSTT1, and CYP2D6 xenobiotics biotransformation genes, which are possible 
risk markers of cancer in populations of indigenous ethnic groups and Russians of North Siberia. Russ J Genet Appl Res. 2012;2(1):7-17.

61. About the approval of the regional program "Combating oncological diseases" THE GOVERNMENT OF THE YAMAL-NENETS AUTONOMOUS OKRUG RESOLUTION of June 24, 2019 No 658-P. http://docs.cntd.ru/ document/553375352 Accessed 30 June 2020.

62. Murzina RR, Karunas AS, Gatiyatullin RF, et al. Research of association of polymorphic variants of gene arylamine- $\mathrm{N}$-acetyltransferase 2 with the development of bronchial asthma in children. Pract Med. 2016;3(95):33-8 (in Russian). ISSN: 2307-3217 (online).

63. Gaikovitch EA, Cascorbi I, Mrozikiewicz PM, et al. Polymorphisms of drugmetabolizing enzymes CYP2C9, CYP2C19, CYP2D6, CYP1A1, NAT2 and of Pglycoprotein in a Russian population. Eur J Clin Pharmacol. 2003;59:303-12.

64. Rabstein S, Unfried K, Ranft U, Illig T. Variation of the N-acetyltransferase 2 gene in a Romanian and a Kyrgyz population. Cancer Epidemiol Biomark Prev. 2006;15(1):138-41.

65. Hamdy Sl, Hiratsuka M, Narahara K, et al. Genotype and allele frequencies of TPMT, NAT2, GST, SULT1A1 and MDR-1 in the Egyptian population. Br I Clin Pharmacol. 2003;55:560-9.

66. Ma Q-W, Lin G-F, Chen J-G, et al. Polymorphism of N-acetyltransferase 2 (NAT2) gene polymorphism in Shanghai population: occupational and nonoccupational bladder cancer patient groups. Biomed Environ Sci. 2004;17: 291-8.

67. WHO best practices for injections and related procedures toolkit. 2010 https:/apps.who.int/iris/bitstream/handle/10665/44298/9789241599252 eng.pdf?sequence $=1$ Accessed 26 Aug 2019

68. Hardy-Weinberg equilibrium. https://ihg.gsf.de/cgi-bin/hw/hwa2.pl Accessed 26 Aug 2019.

69. Biometrics: a journal for physicians and biologists, advocates of evidencebased biomedicin. http://www.biometrica.tomsk.ru/freq2.htm Accessed 26 Aug 2019.

\section{Publisher's Note}

Springer Nature remains neutral with regard to jurisdictional claims in published maps and institutional affiliations.

Ready to submit your research? Choose BMC and benefit from:

- fast, convenient online submission

- thorough peer review by experienced researchers in your field

- rapid publication on acceptance

- support for research data, including large and complex data types

- gold Open Access which fosters wider collaboration and increased citations

- maximum visibility for your research: over $100 \mathrm{M}$ website views per year

At $\mathrm{BMC}$, research is always in progress.

Learn more biomedcentral.com/submissions 